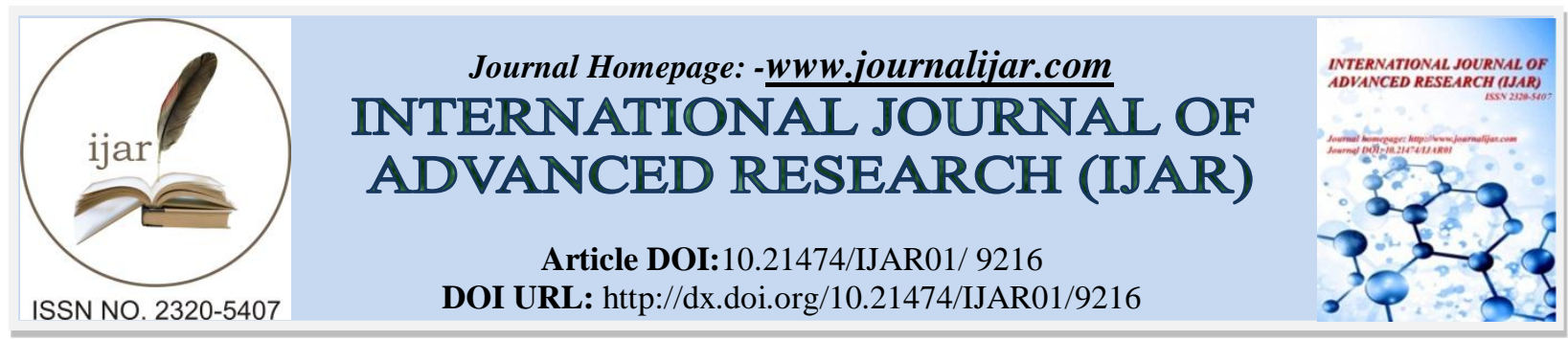

RESEARCH ARTICLE

\title{
TOPICAL PROPRANOLOL THERAPY FOR INFANTILE HEMANGIOMA: A RETROSPECTIVE MULTI-INSTITUTION STUDY IN THE EASTERN REGION OF LIBYA.
}

Salma A. Bukhatwa, Zainab Albrgathi, Zainab Salem, Hanady Faraj and Mariam Ehwiw.

Department of Pharmacology \& Toxicology, Faculty of Pharmacy/ University of Benghazi, Benghazi, Libya.

\section{Manuscript Info}

Manuscript History

Received: 05 April 2019

Final Accepted: 07 May 2019

Published: June 2019

Key words:-

Infantile Hemangioma, Topical

Propranolol, Intralesional Steroids,

\section{Abstract}

There has been a paradigm shift from steroids to propranolol for the pharmacologic treatment of infantile hemangiomas (IHs); however, the outcomes for such treatment were not well studied. In addition, there is no previous published data about the treatment of IHs in Libya.

The purpose of this study is to compare the efficacy of topical propranolol versus intralesional steroid therapy for $\mathrm{IH}$ children in Libya.

A retrospective review was conducted on patients with IH treated with either topical propranolol or intralesional triamcinolone with dexamethasone therapy, during the period 2014 - 2018. Hemangioma characteristics including the time to heal and percentage of lesion size reduction, were compared as per before and after each type of treatment.

Most of the IH cases were females with an age range of 1-6 months. Mean percent reductions in lesion size following both topical propranolol and intralesional triamcinolone with dexamethasone therapy were 53\% and 50\% respectively. Taking into consideration the prominent side effects of using steroids, then, propranolol could replace systemic corticosteroids as first-line therapy for $\mathrm{IH}$.

Copy Right, IJAR, 2019,. All rights reserved.

\section{Introduction:-}

Infantile hemangiomas (IHs) are the most common benign tumor in infants and children. Most cases of IHs occur on the head and neck. IH is characterized by a rapid proliferative phase during early infancy, from birth to approximately 1 year of age, followed by a gradual involution that may last until the age of 10 years. ${ }^{1} \mathrm{IHs}$ are more frequent among females with male to female ratio ranging from $1: 3$ to $1: 5 .^{2}$

Traditional therapy for IH includes long-term and high-dose usage of steroids, which has been reported to be associated with multiple side effects. ${ }^{3}$ In 2008 , Léauté-Labrèze et al. found by accident, that propranolol is an effective treatment for severe hemangiomas of infancy. The beta-blocker has become the new first-line treatment for complicated hemangiomas. ${ }^{4}$ However, the efficacy of propranolol in treating $\mathrm{IH}$ patients is not universal as some propranolol-resistant cases have been reported. ${ }^{5-7}$ Further studies are required to improve the efficacy and reduce side effects of current IH therapies.

In this study we compare the results of treating IH using topical propranolol versus intralesional dexamethasone and triamcinolone therapies.

Address:-Department of Pharmacology \& Toxicology, Faculty of Pharmacy/ University of Benghazi, Libya. 


\section{Materials and Methods:- \\ Design}

Retrospective study included IH cases received either topical propranolol or intralesional triamcinolone with dexamethasone. Children with $\mathrm{IH}$, who were treated with other drugs or dosage forms were excluded from the study.

\section{Data Collection}

This multi-institution study included: dermatology department-Alharamt clinic; located in Ajdabiya city, dermatology department-SARA clinic, Ibn-Sina clinic, and pediatric hospital; the three located in Benghazi city.

\section{Drugs/Dosage forms included in this study Topical propanol $1 \%(\mathrm{w} / \mathrm{w})$ preparation}

It was prepared by use of $1 \mathrm{~g}$ of propranolol per $100 \mathrm{~g}$ of dexapanthelol as a hydrophilic ointment or cream.

\section{Intralesional triamcinolone with dexamethasone injection}

Injections usually consist of $20 \mathrm{mg}$ of triamcinolone acetonide and $3 \mathrm{mg}$ of dexamethasone in $1 \mathrm{ml}$ total volume.

\section{Cases}

Total number of cases is nine (eight females and 1 male) with a median age of 3.3 months (ranges, 1-6 months) at time of start of study.

\section{Recorded Data}

Patients demographics, haemangioma characteristics and treatment data were recorded. Outcome measures including size, shape and subtypes of tumors were monitored and recorded. Response to treatment was evaluated using a 3-point scale system (complete involution - regression - incomplete involution).

\section{Data Analysis}

Data analysis and calculations were done using Microsoft Excel 2010.

Reduction in IH lesion size $(\mathrm{mm})=\mathrm{IH}$ lesion size before treatment $(\mathrm{mm})-\mathrm{IH}$ lesion size after treatment $(\mathrm{mm})$ of $\mathrm{IH}$ lesion size reduction $=$ reduction in $\mathrm{IH}$ lesion size $(\mathrm{mm}) / \mathrm{IH}$ lesion size before treatment $(\mathrm{mm}) * 100$

\section{Results:-}

Nine cases of I.H were included in this study with mean age of 3.3 months (age range, 1-6 months). Females represented $88.89 \%$ of study sample and males represented $11.11 \%$ of study sample (Table 1). Lesion shape and subtype from all cases were monitored and recorded (Table 1).

All treatment details including dose, dosage form, duration of treatment and response to treatment are listed in Table In this study $66.67 \%$ of $\mathrm{IH}$ patients were treated with propranolol, while $33.33 \%$ received steroid therapy. There were reductions in the size of the lesions in all cases (Figures 1,2,3,4 \& Table 2).

Mean percentage reduction in lesion size following propranolol treatment was 53.81\% (Table 3). Mean percentage reduction in lesion size following steroid treatment was $50.00 \%$. (Table 4)

\section{Discussion:-}

According to this study topical propranolol therapy possesses nearly the same effect of intralesional triamcinolone with dexamethasone therapy noting that propranolol has taken 36 months while triamcinolone with dexamethasone 24 months to produce complete or nearly complete cure.

Propranolol is an effective and well-tolerated treatment for IH. Oral propranolol significantly decreases the duration of ulceration in cases of ulcerated infantile hemangiomas with average time to complete healing of ulceration is 4.3 weeks and the mean time to complete pain control is 14.5 days. ${ }^{8,9}$ Usually, treatment duration with propranolol depends on the morphological type of hemangioma and the extent of treatment involvement. Generally, IH needs to be treated for a minimum period of 6 months. In deep and mixed infantile hemangiomas, the duration of treatment is longer because the proliferation phase lasts longer; therefore, treatment is continued until 12-16 months of age. In patients with ulceration, treatment is continued up to 9 to 12 months of age due to the risk of recurrence of ulceration. ${ }^{10}$ Upon discontinuation of propranolol several reports have noted rebound growth or recurrence of the 
treated infantile hemangiomas. ${ }^{11}$ Reported rebound growth was observed in $17 \%$ to $19 \%$ of patients after discontinuation of propranolol, with the time from withdrawal to recurrence ranging from 0 to 6 months. ${ }^{9,12}$ Rebound growth has been attributed to early treatment withdrawal or a long proliferative phase of the infantile hemangioma because in the majority of cases, recurrence occurred in the deep component of the IH. Re-initiation of propranolol is the treatment of choice for rebound growth. ${ }^{13}$

In this study, reduction in lesion size using propranolol was $53.81 \%$ and the treatment was well tolerated without side effects even in children with numerous or large lesions. Topical propranolol (1\%) ointment has also been found efficacious in superficial hemangiomas of the skin. ${ }^{14}$ Propranolol treatment in the proliferative phase within the first 6 months of life, usually induces regression and cessation of growth in haemangioma. Topical $1 \%$ propranolol ointment resulted in various types of responses, with no systemic complication in any of the patients. ${ }^{15,16}$

The mechanism of action of beta-blockers in infantile hemangiomas has not been completely elucidated although they are believed to inhibit tumor growth by at least three distinct mechanisms: (1) vasoconstriction; (2) inhibition of angiogenesis or vasculogenesis by the downregulation of angiogenic factors, vascular endothelial growth factor and basic fibroblast growth factor and (3) induction of apoptosis of capillary endothelial cells. ${ }^{17}$

On the other hand, the mechanism of action of glucocorticoids have been implicated in the acceleration, but not the initiation, of adipocytic differentiation. ${ }^{18}$ The effect of glucocorticoids may depend on promoting apoptosis by means of up-regulation of the mitochondrial cytochrome $b$ gene. ${ }^{19}$ Recent evidence also suggests that glucocorticoids induce adipocytic differentiation through inhibition of pre-adipocyte factor-1 that inhibit adipogenesis. ${ }^{20}$ Another possible action of glucocorticoids involves its effect on peroxisome proliferator-activated receptor, a transcription factor regulating adipocyte differentiation from pre-adipocytes. ${ }^{21}$

The effectiveness of intralesional corticosteroid therapy for problematic was described by numerous studies which suggested that intralesional corticosteroid injection is a safe and effective treatment of $\mathrm{IH}^{22,23}$ In general, corticosteroid injection is reserved for small, bulky, and well localized lesions. Large or diffuse IHs are more difficult to manage with intralesional corticosteroids because of the large volume of injectable steroid that is more likely to cause systemic adverse effects. ${ }^{24,25}$ After corticosteroid injection, large studies have reported accelerated regression in $77 \%$ to $100 \%$ of patients with $\mathrm{IH}$ and cessation of growth in $16 \%$ to $23 \%{ }^{22,23}$ The effects of the steroid last approximately 3 to 4 weeks, and thus patients may require additional treatments during the proliferating phase for rebound growth. ${ }^{26}$ Local complications of intralesional corticosteroids include fat atrophy and hypopigmentation. ${ }^{27}$ Systemic adverse effects can occur if the dose was large (more than $5 \mathrm{mg} / \mathrm{kg}$ ), including cushingoid features 213-217 and adrenal suppression. ${ }^{27}$ A more serious complication of intralesional corticosteroid therapy occurred in lesions of the upper eyelid, with 3 cases of retinal embolization after an injection into lesion of the upper eyelid. ${ }^{28,29}$

Among patients who receive intralesional corticosteroid, ulceration at injection site was the commonest side effect, however, none was persistent. ${ }^{30}$

Previous studies showed that corticosteroids when used as a potent topical preparation, it can improve thin superficial hemangiomas but not their deep components, in addition they have adverse reactions include atrophy and hypopigmentation. ${ }^{31,32}$ Meanwhile, a hydrophilic nonselective beta-blocker was reported to treat periocular hemangiomas successfully without adverse effects. ${ }^{33}$ Side effects due to steroid therapy can be avoided by using propranolol topically and in cases of early intervention in the proliferative phase, propranolol could be able to induce regression or stabilize growth of the hemangiomas within the first 6 months of therapy.

\section{Conclusion:-}

Topical propranolol therapy is effective and safe for the treatment of infantile hemangiomas and it could replace systemic corticosteroids as first-line therapy for complicated hemangiomas of infancy.

\section{Limitations of the study}

Number of cases used in this study is small as retrieving information from health institutions in the eastern region of Libya is difficult. In addition, surgery and laser interventions in the treatment of IH are more common inside Benghazi city; the largest city in the eastern region of Libya. 


\section{Acknowledgments:-}

Authors expresses their sincere gratitude to Dr. Abdulsalam Alfakhry, dermatologist at Alharamat clinic Ajdapia, Dr. Adem Albargathi, opthalmologis at Ibn-Sina clinic, Dr. Mariam Bozgia, dermatologist at SARA clinic, Dr. Najat Elgazal, pediatrician at Benghazi children hospital and the Pharmacist Abdelkarim Albargathi for all the support they gave to this research work.

Table 1: Demographic data of studied cases with description of treatment progress

\begin{tabular}{|c|c|c|c|c|c|c|c|c|c|}
\hline $\begin{array}{l}0 \\
Z \\
\tilde{z} \\
\tilde{\sigma} \\
\tilde{\sigma}\end{array}$ & 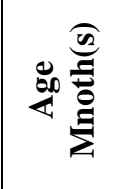 & ฮัల & .气̄ & 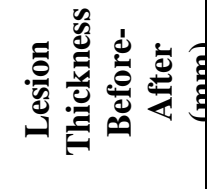 & ஜ̊̊̊ & $\frac{\check{\Xi}}{\tilde{\varpi}}$ & 葛 & ڤ્气 & 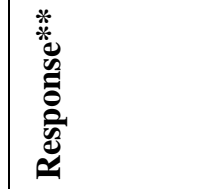 \\
\hline 1 & 2 & Female & Left breast & $2.5-1.5$ & $\begin{array}{l}\% 1 \mathrm{w} \backslash \mathrm{w} \\
\text { Propranolol }\end{array}$ & Focal & Superficial & 6 Months & Regression \\
\hline 2 & 1 & Female & $\begin{array}{l}\text { Right } \\
\text { cheek, } \\
\text { lower lip, } \\
\text { chin \& } \\
\text { extending } \\
\text { down the } \\
\text { neck }\end{array}$ & $4-2$ & $\begin{array}{l}\% 1 w \backslash w \\
\text { Propranolol }\end{array}$ & Large & Mixed & 1 Year & Regression \\
\hline 3 & 2 & Female & $\begin{array}{l}\text { Subumblical } \\
\text { abdominal } \\
\text { skin, just } \\
\text { supra- } \\
\text { pubically }\end{array}$ & $\begin{array}{l}\text { 3- complete } \\
\text { involution }\end{array}$ & $\begin{array}{l}\% 1 w \backslash w \\
\text { Propranolol }\end{array}$ & Focal & Mixed & 3 Years & $\begin{array}{l}\text { Complete } \\
\text { involution }\end{array}$ \\
\hline 4 & 6 & Female & Around lip & $3.2-3.1$ & $\begin{array}{l}\% 1 \mathrm{w} \backslash \mathrm{w} \\
\text { Propranolol }\end{array}$ & Focal & Superficial & 6 Months & - \\
\hline 5 & 3 & Female & Forearm & $3.8-2$ & $\begin{array}{l}\% 1 \mathrm{w} \backslash \mathrm{w} \\
\text { Propranolol }\end{array}$ & Focal & Superficial & 6 Months & - \\
\hline 6 & 3 & Female & Forehead & $4.3-2.1$ & $\begin{array}{l}\% 1 \mathrm{w} \backslash \mathrm{w} \\
\text { Propranolol }\end{array}$ & Large & Mixed & 1 Year & - \\
\hline 7 & 1 & Female & $\begin{array}{l}\text { Over the } \\
\text { upper lid }\end{array}$ & $\begin{array}{c}2 \text { - complete } \\
\text { involution }\end{array}$ & $\begin{array}{l}40 \mathrm{mg} \\
\text { Triamcinolone } \\
4 \mathrm{mg} \\
\text { Dexamethazon } \\
\mathrm{e}\end{array}$ & Large & Mixed & 2 Years & $\begin{array}{l}\text { Complete } \\
\text { involution }\end{array}$ \\
\hline 8 & 6 & Male & $\begin{array}{l}\text { Over the } \\
\text { upper lid }\end{array}$ & $2-1.5$ & $\begin{array}{l}40 \mathrm{mg} \\
\text { Triamcinolone } \\
4 \mathrm{mg} \\
\text { Dexamethazone }\end{array}$ & Large & Mixed & 2 Months & $\begin{array}{l}\text { Incomplete - } \\
\text { good to } \\
\text { release }\end{array}$ \\
\hline 9 & 6 & Female & $\begin{array}{l}\text { Over the } \\
\text { upper lid }\end{array}$ & $2-1.5$ & $\begin{array}{l}40 \mathrm{mg} \\
\text { Triamcinolone } \\
4 \mathrm{mg} \\
\text { Dexamethazone }\end{array}$ & Large & Mixed & 6 Weeks & $\begin{array}{l}\text { Incomplete- } \\
\text { good to } \\
\text { release }\end{array}$ \\
\hline
\end{tabular}

\footnotetext{
*Superficial or mixed $\quad * *$ Complete involution, regression or incomplete involution
} 

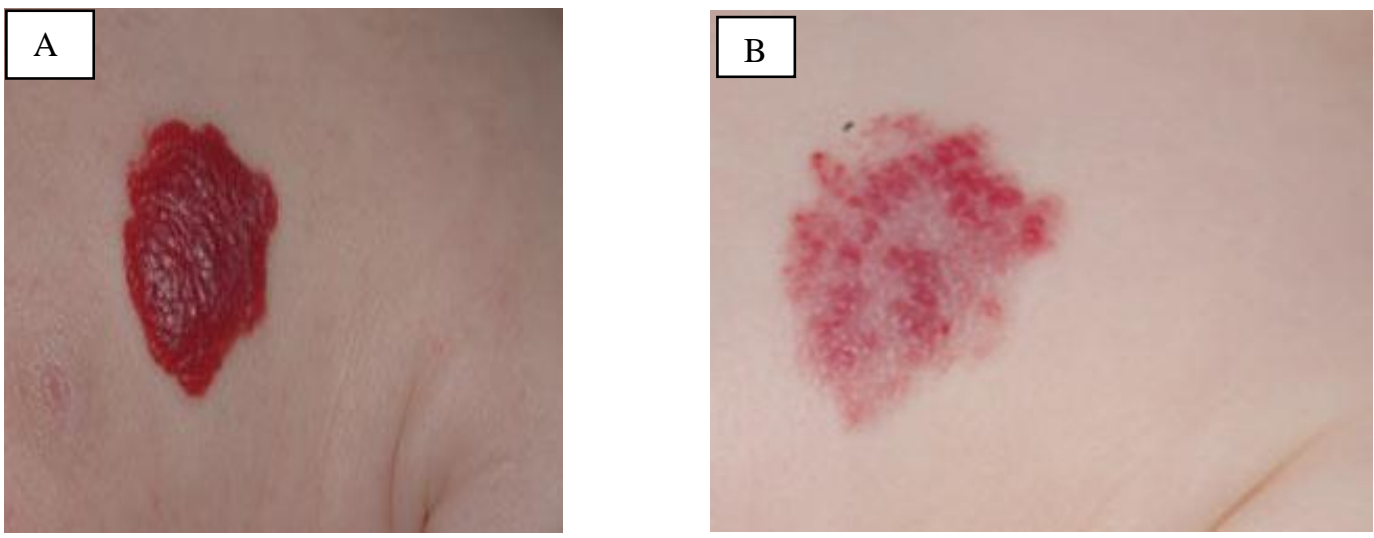

Figure 1: Photographs of case 1 haemangioma at left breast (A) before, (B) 6 months after the initiation of topical propranolol therapy.
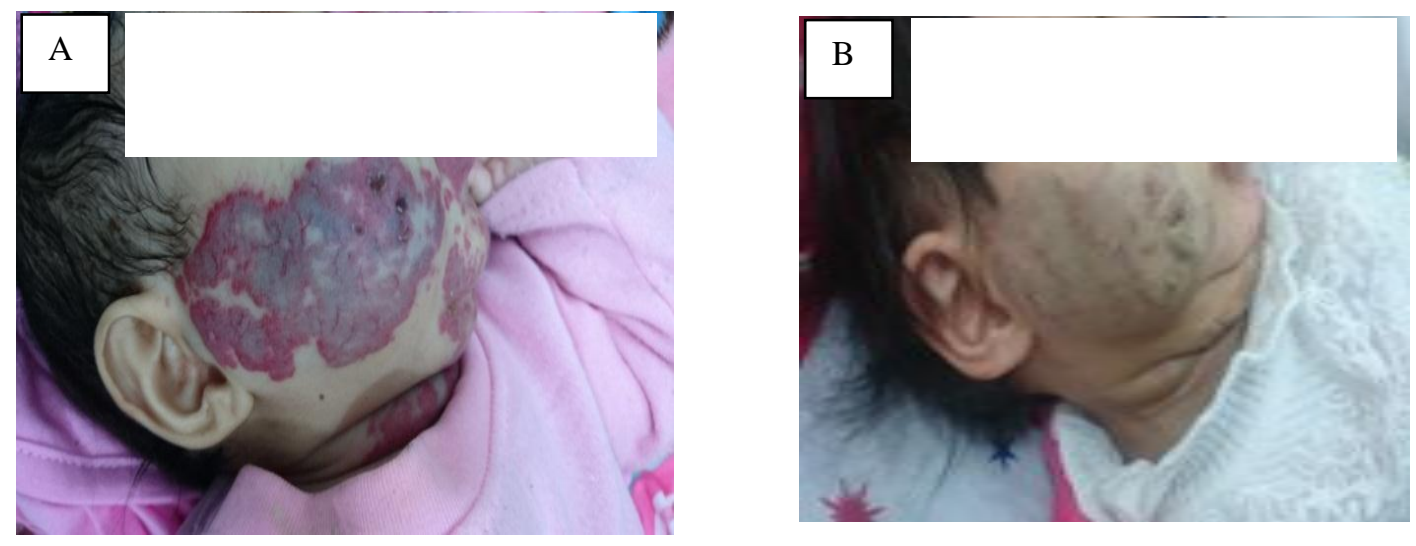

Figure 2: Photographs of case 2 haemangioma at right cheek, lower lip, chin, extended down the neck (A) before (B) 1 year after the initiation of topical propanol therapy.
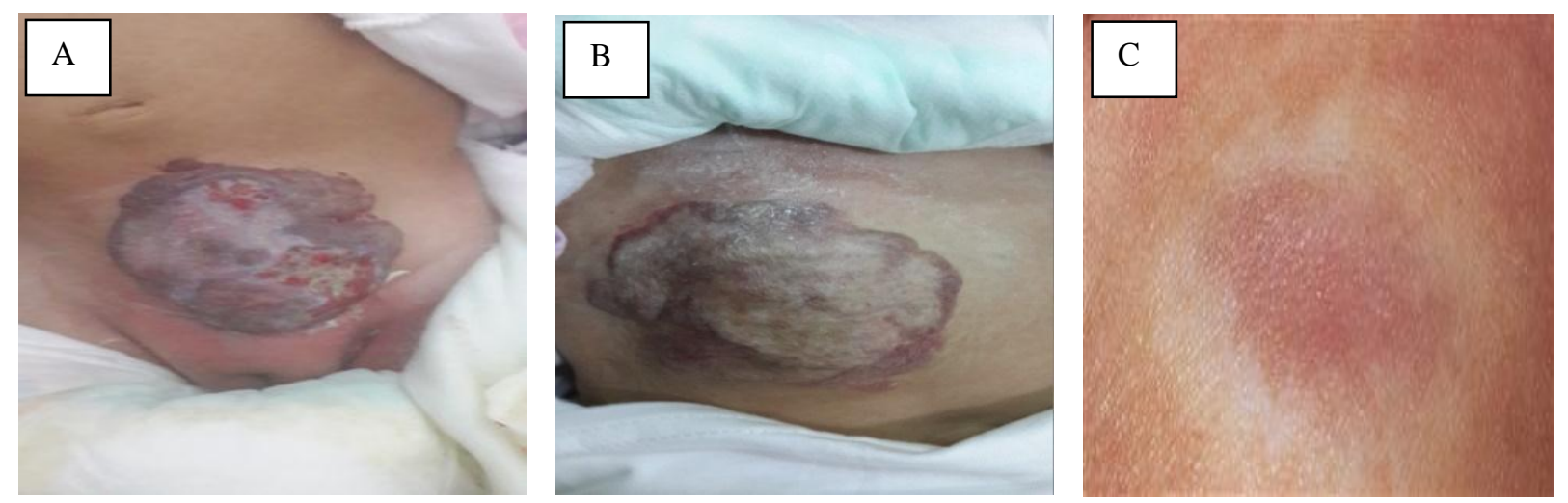

Figure 3: Photographs of case 3 congenital haemangioma at her subumblical abdominal skin, just suprapubical (A) before, (B) 4 months after the initiation of topical propranolol therapy and (C) at the age of 3 years almost complete involution. 

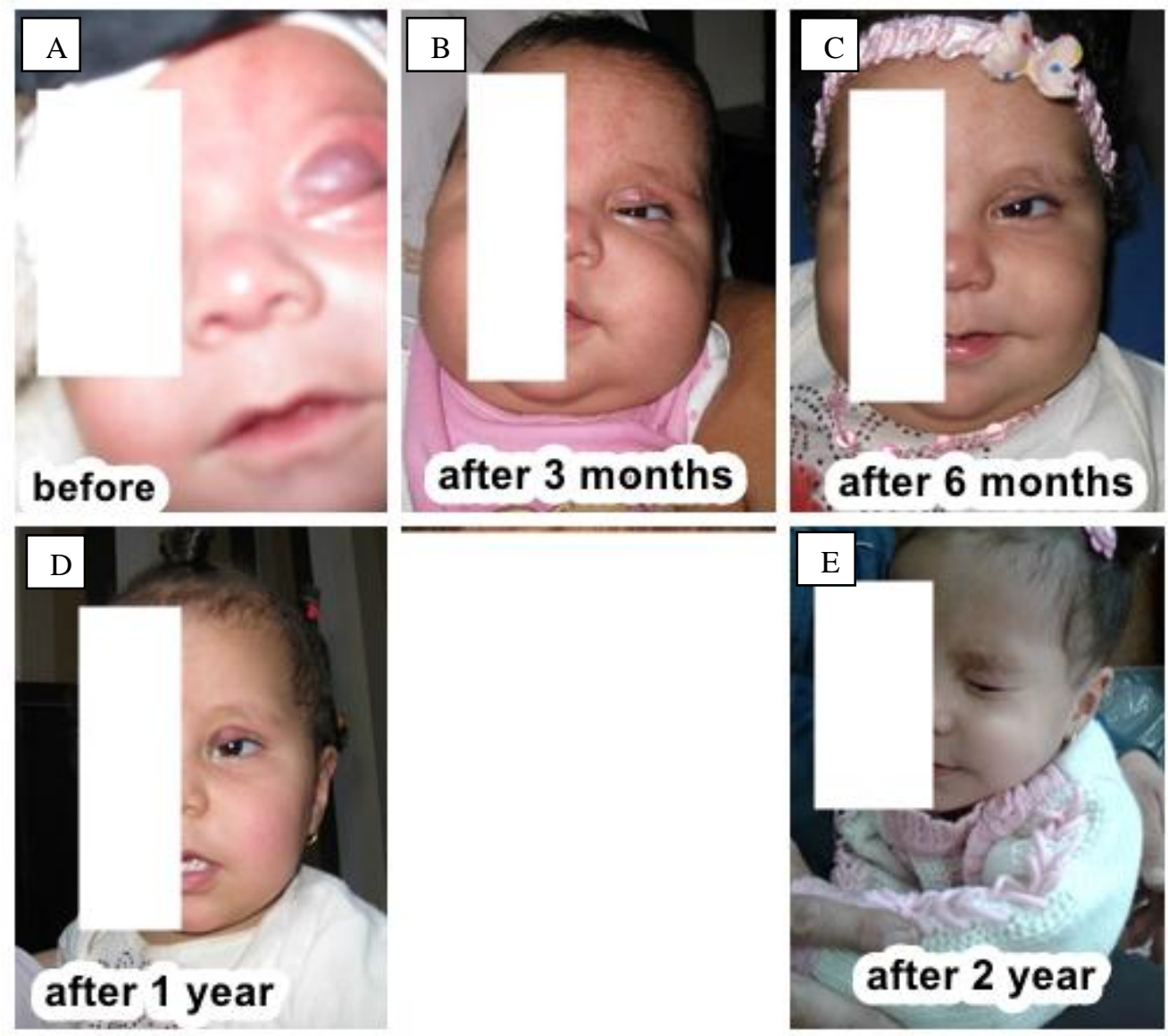

Figure 4: Photographs of case 7 haemangioma at eyelid (A) before (B) 3 months (C) 6 months (D) 1 year of treatment and (E) 2 years after the initiation of intralesional triamcinolone acetonide with dexamethasone therapy.

Table 2: Percentage of reduction in infantile haemangioma lesion size from all studied cases

\begin{tabular}{|l|l|l|l|l|}
\hline & \multicolumn{2}{|l|}{ IH lesion thickness in mm } & \\
\hline & $\begin{array}{l}\text { Before } \\
\text { treatment }\end{array}$ & After treatment & Reduction & \% Reduction in IH lesion size \\
\hline Case1 & 2.5 & 1.5 & 1 & 40.00 \\
\hline Case2 & 4 & 2 & 2 & 50.00 \\
\hline Case3 & 3 & 0 & 3 & 100.00 \\
\hline Case4 & 3.2 & 2.1 & 1.1 & 34.38 \\
\hline Case5 & 3.8 & 2 & 1.8 & 47.37 \\
\hline Case6 & 4.3 & 2.1 & 2.2 & 51.16 \\
\hline Case7 & 2 & 0 & 2 & 100.00 \\
\hline Case8 & 2 & 1.5 & 0.5 & 25.00 \\
\hline Case9 & 2 & 1.5 & 0.5 & 25.00 \\
\hline
\end{tabular}

Table 3: Percentage of reduction in infantile haemangioma lesion size following topical propranolol therapy

Topical Propranolol

\begin{tabular}{|l|l|l|}
\hline Case & Duration of treatment & \% Reduction in IH lesion size \\
\hline case 4 & 6 & 34.38 \\
\hline case 1 & 6 & 40 \\
\hline case 5 & 6 & 47.37 \\
\hline case 2 & 12 & 50 \\
\hline case 6 & 12 & 51.16 \\
\hline case 3 & 36 & 100 \\
\hline
\end{tabular}




\begin{tabular}{|l|l|l|}
\hline Mean & 13 & $53.81 \%$ \\
\hline
\end{tabular}

Table 4: Percentage of reduction in infantile haemangioma lesion size following intralesional steroid therapy

\begin{tabular}{|l|l|l|}
\hline \multicolumn{2}{|l|}{ Intralesional triamcinolone + dexamethasone } \\
\hline Case & Duration of treatment & \% Reduction in IH lesion size \\
\hline case 9 & 1.5 & 25 \\
\hline case 8 & 2 & 25 \\
\hline case 7 & 24 & 100 \\
\hline Mean & 9.16 & $50 \%$ \\
\hline
\end{tabular}

\section{References:-}

1. Marler, J.J., Mulliken, J.B. (2005) Current management of hemangiomas and vascular malformations. Clin. Plast. Surg., 32:99-116

2. Zheng, J.W., Zhang, I., Zhou, Q., Mai, H.M., Wang, Y.A., Fan, X.D., Qin, Z.pP., Wang, K., Zhao, Y.F. (2013) A Practical guide to treatment of infantile hemangiomas of the head and neck. Int. J. Clin. Exp. Med., 6(10):851-60

3. Fawcett, S.L., Grant, I., Hall, P.N., Kelsall, A.W.R., Nicholson, J.C. (2004) Vincristine as a treatment for a large haemangioma threatening vital functions. Br. J. Plast. Surg., 57:168-171

4. Léauté-Labrèze, C., Dumas de la Roque, E., Hubiche, T., Boralevi, F., Thambo, J.B., Ta ïeb, A. (2008) Propranolol for severe hemangiomas of infancy. N. Engl. J. Med., 358(24):2649-2651

5. Hogeling, M., Adams, S., Wargon, O. (2011) A randomized controlled trial of propranolol for infantile hemangiomas. Pediatrics, 128(2): e259-266

6. Goswamy, J., Rothera, M.P., Bruce, I.A. (2011) Failure of propranolol in the treatment of childhood haemangiomas of the head and neck. J. Laryngol. Otol.,125(11):1164-1172

7. Caussé, S., Aubert, H., Saint-Jean, M., Puzenat, E., Bursztejn, A.C., Eschard, C., Mahe, E., Maruani, A., Mazereeuw-Hautier, J., Dreyfus, I., Miquel, J., Chiaverini, C., Boccara, O., Hadj-Rabia, S., Stalder, J.F., Barbarot, S. (2013) Propranolol-resistant infantile haemangiomas. Br. J. Dermatol.,169(1):125-129

8. Hermans, D.J., van Beynum, I.M., Schultze Kool, L.J., van de Kerkhof, P.C., Wijnen, M.H., van der Vleuten, C.J. (2011) Propranolol, a very promising treatment for ulceration in infantile hemangiomas: A study of 20 cases with matched historical controls. J. Am. Acad. Dermatol., 64(5):833-838

9. Saint-Jean, M., Léauté-Labrèze, C., Mazereeuw-Hautier, J., Bodak, N., Hamel-Teillac, D., Kupfer-Bessaguet, I., Lacour, J.P., Naouri, M., Vabres, P., Hadj-Rabia, S., Nguyen, J.M., Stalder, J.F., Barbarot, S. (2011) Propranolol for treatment of ulcerated infantile hemangiomas. J. Am. Acad. Dermatol., 64(5):827-832

10. Mansouri, P., Hejazi, S., Ranjbar, M., Shakoei, S. (2014) Propranolol in infantile hemangioma: A review article. J. Skin Stem Cell, 1:e22884

11. Giachetti, A., Garcia-Monaco, R., Sojo, M., Scacchi, M.F., Cernadas, C., Guerchicoff Lemcke, M., Dovasio, F. (2014) Long-term treatment with oral propranolol reduces relapses of infantile hemangiomas. Pediatr. Dermatol. 31(1):14-20

12. Bagazgoitia, L., Torrelo, A., Gutierrez, J.C., Hernandez-Martin, A., Luna, P., Gutierrez, M., Bano, A., Tamariz, A., Larralde, M., Alvarez, R., Pardo, N., Baselga, E. (2011) Propranolol for infantile hemangiomas. Pediatr. Dermatol., 28(2):108-114

13. Shehata, N., Powell, J., Dubois, J., Hatami, A., Rousseau, E., Ondrejchak, S., McCuaig, C. (2013) Late rebound of infantile hemangioma after cessation of oral propranolol. Pediatr. Dermatol., 30(5):587-591

14. Kunzi-Rapp, K. (2012) Topical propranolol therapy for infantile hemangiomas. Pediatr. Dermatol., 29(2): 154159

15. Bonifazi, E., Colonna, V., Mazzotta, F., Balducci, G., Laforgia, N. (2008) Propranolol in rapidly growing hemangiomas. Eur. J. Pediatr. Dermatol.,18(3):185-92

16. Xu G, Lv. R., Zhao, Z., Huo, R. (2012) Topical propranolol for treatment of superficial infantile hemangiomas. J. Am. Acad. Dermatol. 67(6):1210-1213

17. Storch, C.H., Hoeger, P.H. (2010) Propranolol for infantile haemangiomas: insights into the molecular mechanisms of action. Br. J. Dermatol., 163(2):269-274

18. Chapman, A.B., Knight, D.M., Ringold, G.M. (1985) Glucocorticoid regulation of adipocyte differentiation: Hormonal triggering of the developmental program and induction of a differentiation-dependent gene. J. Cell. Biol.,101(4):1227-1235 
19. Hasan, Q., Tan, S.T., Gush, J., Peters, S.G., Davis, P.F. (2000) Steroid therapy of a proliferating hemangioma: Histochemical and molecular changes. Pediatrics, 105:117- 120

20. Pantoja, C., Huff, J.T., Yamamoto, K.R. (2008) Glucocorticoid signaling defines a novel commitment state during adipogenesis in vitro. Mol. Biol. Cell, 19:4032-4041

21. Ameshima, S., Golpon, H., Cool, C.D., Chan, D., Vandivier, R.W., Gardai, S.J., Wick, M., Nemenoff, R.A., Geraci, M.W., Voelkel, N.F. (2003) Peroxisome proliferator-activated receptor gamma (PPARgamma) expression is decreased in pulmonary hypertension and affects endothelial cell growth. Circ. Res., 92(10):11621169

22. Azzolini, A., Nouvenne, R. (1970) Nuove prospettive nella terapia degli angiomi immaturi dell'infanzia, 115 lesione; trattate con infiltrazioni; intralesionali di triamcinolone acetonide. Acta Biol. Med. (Gdansk)., 41(suppl 1):41-51

23. Samimi, D.B., Alabiad, C.R., Tse, D.T. (2012) An anatomically based approach to intralesional corticosteroid injection for eyelid capillary hemangiomas. Ophthalmic Surg. Lasers Imaging., 43(3):190-195

24. Goyal, R., Watts, P., Lane, C.M., Beck, L., Gregory, J.W. (2004) Adrenal suppression and failure to thrive after steroid injections for periocular hemangioma. Ophthalmology,111(2):389-395

25. Prasetyono, T.O.H., Djoenaedi, I. (2011) Efficacy of intralesional steroid injection in head and neck hemangioma: a systematic review. Ann. Plast. Surg. 66(1): 98-106

26. Buckmiller, L.M., Munson, P.D., Dyamenahalli, U., Dai, Y., Richter, G.T. (2010) Propranolol for infantile hemangiomas: Early experience at a tertiary vascular anomalies center. Laryngoscope, 120(4):676-681.

27. Sloan, G.M., Reinisch, J.F., Nichter, L.S., Saber, W.L., Lew, K., Morwood, D.T. (1989) Intralesional corticosteroid therapy for infantile hemangiomas. Plast. Reconstr. Surg., 83(3):459-467

28. Egbert, J.E., Schwartz, G.S., Walsh, A.W. (1996) Diagnosis and treatment of an ophthalmic artery occlusion during an intralesional injection of corticosteroid into an eyelid capillary hemangioma. Am. J. Ophthalmol., 121(6):638-642

29. Egbert, J.E., Paul, S., Engel, W.K., Summers, C.G. (2001) High injection pressure during intralesional injection of corticosteroids into capillary hemangiomas. Arch. Ophthalmol., 119(5):677-683

30. Gangopadhyay, A.N., Sharma, S.P., Gopal, S.C., Gupta, D.K., Panjawani, K., Sinha, J.K. (1996) Local steroid therapy in cutaneous hemangioma. Indian Pediatr., 33(1): 31-33

31. Ranchod, T.M., Frieden, I.J., Fredrick, D.R. (2005) Corticosteroid treatment of periorbital haemangioma of infancy: a review of the evidence. Br. J. Ophthalmol. 89(9):1134-1138

32. Ho, N.T.C., Lansang, P., Pope, E. (2007) Topical imiquimod in the treatment of infantile hemangiomas: a retrospective study. J. Am. Acad. Dermatol. 56(1):63-68

33. Guo, S., Ni, N. (2010) Topical treatment for capillary hemangioma of the eyelid using beta-blocker solution. Arch. Ophthalmol., 128(2):255-256. 